Canadian University Music Review

Canadian University Music Review

Revue de musique des universités canadiennes

\title{
Musical-Rhetorical Prosopopoeia and the Animation of the Dead in Seventeenth-Century German Funeral Music
}

\section{Gregory S. Johnston}

Volume 10, numéro 1, 1990

URI : https://id.erudit.org/iderudit/1014893ar

DOI : https://doi.org/10.7202/1014893ar

Aller au sommaire du numéro

Éditeur(s)

Canadian University Music Society / Société de musique des universités canadiennes

ISSN

0710-0353 (imprimé)

2291-2436 (numérique)

Découvrir la revue

Citer cet article

Johnston, G. S. (1990). Musical-Rhetorical Prosopopoeia and the Animation of the Dead in Seventeenth-Century German Funeral Music. Canadian University Music Review / Revue de musique des universités canadiennes, 10(1), 12-39. https://doi.org/10.7202/1014893ar

All Rights Reserved @ Canadian University Music Society / Société de musique des universités canadiennes, 1990
Ce document est protégé par la loi sur le droit d'auteur. L’utilisation des services d'Érudit (y compris la reproduction) est assujettie à sa politique d'utilisation que vous pouvez consulter en ligne.

https://apropos.erudit.org/fr/usagers/politique-dutilisation/ 


\section{MUSICAL-RHETORICAL PROSOPOPOEIA AND THE ANIMATION OF THE DEAD IN SEVENTEENTH-CENTURY GERMAN FUNERAL MUSIC*}

Gregory S. Johnston

Funeral music accounts for more than half of the occasional music written in Germany in the seventeenth century (Weinhold 1972: 172), yet as a genre it has received critical attention from very few scholars. Commenting upon this relatively unexplored body of music, Günter Graulich, Paul Horn and Klaus Hofmann state in the preface to Graulich's edition of Heinrich Schütz's Musikalische Exequien that "an investigation of the genre itself and its musicorhetorical content would certainly uncover much of interest" (Graulich 1973: xxiv). Indeed, Protestant funeral music of the seventeenth century embodies a rhetoric as eloquent as it is diverse. The present essay is a survey of a single rhetorical trope known as prosopopoeia ( $\pi \rho 0 \sigma \omega \pi 0 \pi 0 l i \alpha)$, which may be defined briefly as an oratorical device whereby abstractions or inanimate objects are invested with human qualities or abilities (Corbett 1971: 485) in short, personification. Rhetorical personification of the dead was frequently employed in Baroque funeral oratory of the Lutheran Church and, as will be shown here, was likewise used extensively and to good effect by German composers of Baroque funeral music.

Personification was already recognized as an effective oratorical trope during rhetoric's formative years in ancient Greece and Rome, and in judging from Baroque rhetoric manuals, it had lost none of its persuasive force by the seventeenth century. In the Triumphus Bibliorum Sacrorum of 1625, Johann Heinrich Alsted (1588-1638), rhetorician, composer and champion of Calvinism, observes that prosopopoeia, "in serious matters, for instance in admonitions

* An earlier version of this paper was read at the Annual Meeting of the Canadian University Music Society in Winnipeg, 1986. I wish to thank the Social Sciences and Humanities Research Council of Canada for support in the research, and Professor Gregory G. Butler for helpful criticism. 
and vehement reproaches, is a remarkable figure" (Alsted 1625: 9. 9. 483). ${ }^{1}$ Johann Matthäus Meyfart (1590-1642), in his Teutsche Rhetorica oder Redekunst of 1634, illustrates his definition of prosopopoeia with an example taken from the pseudo-Ciceronian Rhetorica ad Herennium where the dead Lucius Brutus is invested with the ability to speak (Meyfart 1634: 1: 387). Fortyeight years later, the same example, this time in the original Latin, is used to illustrate the definition of prosopopoeia given in the Compendium Rhetorices of 1682 by Christoph Kaldenbach (1613-98), who at that time was active as a composer and as a professor of rhetoric at the University in Tübingen (Kaldenbach 1682/1709: 137).

Prosopopoeia thrived in what Ferdinand van Ingen refers to as the Augenkultur ("visual culture") of Baroque Germany (van Ingen 1966: 299). In his book Vanitas und Memento Mori in der deutschen Barocklyrik, van Ingen examines the literary and visual arts in their capacity to provide a representational nexus between the here and now and the hereafter. In the visual arts this union was achieved with dramatic effect through the realistic depiction of celestial scenes in paintings typically found in Baroque churches and chapels. In the ceiling frescoes in particular, the eye is often beguiled by the artist's skilful handling of colour and perspective as architectural lines of the church are extended into the painting itself. Consequently, and in powerful visual terms, the church becomes the median in a continuum that reaches from the congregation of worshipers to the portals of Paradise. The paintings, serving more than a purely decorative function, in part provided the contemplative Christian with visual stimuli to stir the imagination towards sublime thoughts of liberation and salvation, resurrection and eternal life. In the literary arts a similar effect was achieved through prosopopoeia, evoking comparable prophetic images in the minds of the listeners. When personifying the dead in the context of the seventeenth-century funeral ceremony, the pastor was not speaking in his own behalf, but rather was acting in the capacity of a medium transmitting to the congregation consolatory and admonitory messages from beyond the grave. The clearer, the more vivid the images set forth by the orator, the easier it was for him to move the affections of the audience.

The success of prosopopoeia was the result of allowing rhetorical persuasion to take place simultaneously on logical, ethical and pathetic levels - the three Aristotelian means of persuasion (Rhetoric 3. 1). ${ }^{2}$ Through the proso-

1 “. . . in rebus gravioribus, puta in admonitionibus et objurgationibus vehementioribus, est ornatum praestabile." Quoted in Dyck 1966: 94.

2 See Cooper 1932: 182. 
popoeial evocation of the dead, the rhetor donned the persona of the deceased, speaking as though he were in fact the deceased. In so doing, the implied premises are laid out for an effective quasi-syllogistic argument or enthymeme. Though untenable in terms of strict syllogism, his rhetorical argument was logically sound nonetheless. It thus follows that if the personified voice of the deceased was actually heard to profess the reality of resurrection and the existence of eternal life, one could only deduce from the premises that the testimony must be true.

By adopting the identity of the deceased in the writing and delivery of a funeral sermon, the pastor as rhetor was able to strengthen the ethical side of the oration, that is, to enhance his own character in the eyes of the congregation. Through animating the dead, the pastor would immediately become associated with the deceased (Rhetoric 3.17 ) ${ }^{3}$ and since the congregation was chiefly comprised of mourners the psychological association would have been a favourable one. As a result of the orator's heightened ethical status, the congregation would have been more attentive and receptive than otherwise to attitudes and dogma expressed by the speaker, attitudes which perhaps were not entirely characteristic of the deceased. Even if the personification were a complete fabrication, if everything said by the orator were his ideas alone but expressed as the posthumous thoughts and epiphanic visions of the deceased, the congregation, unwilling to dispute the voice of the person whom they mourned, would nevertheless have felt compelled to give credence to the speaker.

It was as a pathetic argument, however, that prosopopoeia was most powerful, and funeral ceremonies provided a context in which emotions were most easily affected. In personifying the dead, it was not just the words of the deceased that the orator animated; it was the tones and patterns of the deceased's voice and, when appropriate or effective, even his or her gestures. When we read sections of Baroque funeral sermons in which personification is involved, we must assume that the skilled rhetor would at least feign the emotions expressed in the text. In the Trauer-Rede written in 1693 for the funeral of Sigismund Heinrich, Baron of Bibran and Modlau, the orator personifies, at different times, the bereft widow, the children and the Baron's brother. In each of these instances the lamenting text is rhetorically laden with pathos:

Alas! I see now before me the tears of a deeply grieving widow who sadly weeps . . . , she cries to the Lord her God: See, Lord, how sorely I am distressed. My bowels writhe in anguish: at home Death has made me a widow.

Ibid.: 236-37. 
The almighty hath dealt very bitterly with me. For these things I weep; mine eye, mine eye runneth down with water, because the comforter that should relieve my soul is far from me. (Silanô-Silesius, I. N. I!, 1693: 15) ${ }^{4}$

Later in the service, the Baron himself is called upon to offer consolation to the mourners, providing a soothing counter to the widow's plaint.

"The final hour comes like a thief" ("Die lezte Stund kommt als ein Dieb") was a familiar maxim in seventeenth-century Germany (Zeller 1975: 71). Death was rarely out of sight and seldom out of mind: infant mortality was extraordinarily high, plague and any number of other epidemics were seasonal occurrences, and the horrible effects of the Thirty Years' War were no less devastating. Because of death's omnipresence in the lives and minds of all, the Lutheran clergy promoted the sedulous study of the medieval ars moriendi. Tens of thousands of funeral sermons were published and bound into anthologies for church members to study and contemplate in order to prepare spiritually for death. Based on the experiences of others who had preceded them, Lutherans learned in this way how best to prepare for death, how to die a proper Christian death, how to cross most peacefully the threshold from this world into the next. And many did not stop at spiritual preparation. It was common among Lutherans to choose biblical verses or chorale texts to be used as themes for their funeral sermons, to dictate curriculum vitae to be read at the funeral, or to select specific chorales or commission works in advance for the choir to sing. Such was this preoccupation with death that women occasionally made their own shrouds (and no doubt those required for the members of the household), and others sometimes went so far as to plan and supervise full dress rehearsals of their funerals. The Mansfeld pastor Caspar Titius, in his Loci Theologici Historici of 1684, describes the effect of people having composed their own funeral sermons. When the body was brought into the church for the funeral, it was a Lutheran custom in the seventeenth century to place the body in its coffin directly beneath the pulpit, thus occupying a communicative point midway between the speaker and his audience. When the funeral sermon was then delivered, the congregation of mourners did not necessarily hear the priest comforting and admonishing them, but rather heard

4 “Ach! ich sehe anitzo vor mir Thränen einer tief-Leidetragenden Witwen / welche herzlich weinet . . . / schreiet Sie zu dem HErren ihrem GOtt / was Sie immer kann: Ach HERR! Siehe doch/wie bange ist mir/in meinem Leibe/denn ich bin höchstbetrübet: der Todt hat mich im Hause zur Witwen gemacht. Thren. 1/20. der Allmächtige hat mich sehr betrübt. Ruth. 1/2[0]. darum weine ich so / und meine beide Augen flüssen mit Wasser / dass der Tröster / der meine Seele solte erkwikken / ferne von mir ist / Thren. 1/16." 
"the deceased himself preaching by means of prosopopoeia from the coffin" (Titius 1684: 1291). ${ }^{5}$ In the most unexceptional of funeral services, circumstances alone would have been cause for a moving emotional experience; and where the orator ornamented the sermon with the occasional prosopopoeial passage, the sentiments of the congregation would no doubt have been deeply touched; but where the orator delivered a sermon written by the deceased personally addressing specific members of the congregation, perhaps going so far as to mimic the speech patterns and physical mannerisms of the deceased, we today can scarcely begin to imagine the impact this would have had on the sensibilities of society of that time.

German composers were certainly familiar with the concept of prosopopoeia in its theoretical and practical literary sense. Steeped in the humanistic tradition of German schools and universities, and eventually employed either by the Church or appointed to an aristocratic court, composers were by and large well-educated men. Having obtained a solid linguistic foundation in the Lateinschulen, most composers initially pursued advanced studies in either theology or law at university, disciplines which required of them a thorough mastery of classical rhetoric. They would certainly have studied prosopopoeia in their rhetorical studies; they would have seen the effectiveness of its application in funerary sermonic oratory, and would similarly have noticed that the odes or epicedia typically found in published Leichenpredigten (to which they themselves regularly contributed) were often conceived as personifications of the deceased and were simply entitled "Prosopopoeia." Just how conscious were composers of the concept of prosopopoeia can be seen in a single published work from 1634 by Johann Kemp, the Court Cantor and Imperial Poet Laureate in Güstrow. The publication consists of two funeral motets for the late Anna Maria, Duchess of Mecklenburg, and a poem by Kemp entitled Prosopopoeia, in which the late Duchess consoles her surviving husband (Kemp 1634).

In its simplest application, prosopopoeia can be seen in the traditional and newly composed hymns and chorales found in seventeenth-century cantionale. Compositions in the so-called cantional style, by far the most commonly performed at funerals, were sung either homophonically by the choir alone, or monophonically by the congregation with the harmonic support of the choir. Usually scored for four (SATB) or five (SSATB) parts, these compositions are characterized by their syllabic settings of strophic texts.

5 ... gleichsam per prosopopoiian den Verstorbenen selbst aus dem Sarge herfürpredigen." Quoted in Zeller 1975: 67. 
One of the most enduring and influential of the seventeenth-century cantionale is Johann Hermann Schein's Cantional oder Gesangbuch Augsburgischer Konfession. First published at Leipzig in 1627, Schein's collection enjoyed such popularity in Lutheran Germany that an expanded version of it was reissued in 1645 by Schein's successor at St Thomas, Tobias Michael. The 1627 edition of the Cantional contains a proportionately large number of compositions (approximately one quarter of the total) written specifically for, or favourably suited to, performance at funerals. Under the heading "At Funerals" (Bey Begräbnissen) in the prefacing Kirchenordnung (Schein 1627/45: xv-xvi), seventy-four compositions are mentioned: five of them by name (nos. 151, $187,188,190,196 \mathrm{a}-\mathrm{b})$, forty-eight by number under the subheading "Of Death and Dying" (Vom Tod vnd Sterben, nos. 216-63), and twenty-one under the general subheading "Psalm." Additionally, at least two other works from the Cantional (nos. 28, 29) served as funerary compositions and are subsumed under the heading "At the Feast of the Purification of the Virgin Mary" (Am Tage Mariae Reinigung). The 1645 edition is supplemented with an additional twenty-two funerary works by Schein himself and five by Michael. Because of Schein's far-reaching musical and poetic influence on Lutheran church music in the seventeenth century, his collection will serve here to demonstrate the manner in which personification was applied to Baroque funerary compositions in the cantional style.

Despite the inherent musical restrictions of these works, there is extensive use of personification in the Cantional. Though the music closely conforms to the cantional style, the texts themselves display considerable poetic imagination. Several of the pieces portray the deceased addressing God or Jesus (nos. 29, $216,223,289,303)$. Through these supplications, the subject serves as a model Christian and his death an exemplary end. The deceased in these instances petitions the Lord, thereby giving utterance to Church doctrine in matters of death, salvation, resurrection and eternal life. The gathered mourners, made party to these petitions, are meant to find consolation in their sorrow and renewed strength in their Lutheran faith. Typical of these compositions, the following verse taken from "Wenn mein Stündlein vorhanden ist" (no. 223) aptly demonstrates the consolatory manner in which the departed addresses the Lord.

6 Settings in Schein's Cantional said to be suited to performance at funerals are: 139 (Ps. 6), 143 (Ps. 13), 145 (Ps. 15), 148 (Ps. 23), 149 (Ps. 25), 150 (Ps. 30), 151 (Ps. 31), 153 (Ps. 39), 154 (Ps. 42), 157 and 158 (Ps. 51), 164 (Ps. 84), 165 (Ps. 88), 166 (Ps. 90), 171 (Ps. 112), 172 (Ps. 116), 174 (Ps. 121), 178 (Ps. 126), 181 (Ps. 130), 184 (Ps. 142), 185 (Ps. 146). 
4. Weil du vom Tod erstanden bist, werd ich im Grab nicht bleiben; mein höchster Trost dein Auffahrt ist, Tods Furcht kann sie vertreiben. Denn wo du bist, da komm ich hin, dass ich stets bei dir leb und bin; drum fahr ich hin mit Freuden.
Because Thou art risen from the dead, I shall not remain in the grave; Thine ascent is my greatest comfort It can drive away fear of death. For where Thou art, there come I, That I might always live and be with Thee; Therefore I die with happiness.

Elsewhere in the Cantional, the deceased first addresses the Lord as in the pieces just mentioned, but then turns his attention towards the mourning congregation (nos. 224, 259,288, 295) or specifically towards members of the family (no. 222), comforting the congregation vicariously by entreating God and directly by addressing the mourners themselves. "Klagt mich nicht mehr, ihr lieben Leut" (no. 259), a hymn originally composed for the funeral in 1620 of a certain Katharina Pose (Bose), is a good example of this type of prosopopoeia. Described in the Cantional as being suitable "For the Funeral of a Spouse" (Bey Begräbnis eines Ehegatten), the composition begins with the deceased's addressing the congregation in verses $1-3$, God in verse 4 , the husband (alternatively the wife) in verses 5-6, the children in verse 7 , and the general assembly of mourners in verse 8 . With the closing verse, Schein ingeniously transports the mourners from a passive to an active role in the rhetorical process by having the deceased call upon them to sing the ensuing Sanctus.

There are numerous instances where the deceased speaks directly to the congregation (nos. 235, 251, 254, 297) and others in which the deceased addresses the assembly of mourners, with special remarks directed towards the members of the surviving family (nos. 246, 247, 253, 255, 256). "Ihr lieben Trauerleut" (no. 297), for example, was composed by Schein in 1629 for the funeral of Johannes Elfeld and later was incorporated by Michael into the 1645 edition of the Cantional. In the course of the nine verses of text, the deceased informs the mourners that he was victorious in his spiritual battle, freed now of his desires for the vain and transitory pleasures of a temporal existence. For these reasons, based seemingly on his own experience, the animate Elfeld adjures the mourners to put an end to their mourning, admonishes them to keep their faith, and concludes his final address with a blessing and farewell.

Although the application of prosopopoeia and its effectiveness in the cantional style were restricted to a purely textual level, there are several compositions in which Schein strove as far as possible to impart a perceived spiritual presence of the deceased. Some pieces, which originally had been composed for the funeral of a particular person, were thought by Schein to be better suited than others to performance at later funerals. For instance, nos. 253 and 259 are 
identified as being especially appropriate "at [the] funeral of a spouse" (bey Begräbnis eines Ehegatten) because the personified deceased in each case addresses the widow(er) and children. Similarly, nos. 255 and 287 were recommended for performances "at [the] funeral of a minister" (bey Bestattung eines Seelsorgers), and the diminutive forms of words in no. 224 ("Hie lieg ich armes Würmelein") made that work most appropriate "at the funeral of small children" (bey dem Begräbnis der kleinen Kinderlein). In no. 256, which was deemed best suited for performance "at [the] funeral of a school teacher" (Bey Begräbnis eines Schuldieners), the text closes with the deceased blessing and admonishing his colleagues and students:

10. Mein liebste Herrn Kollegen all, seid eurem Gott nur treu, er wirds vergelten gwiss einmal mit Segen mancherlei. Und, o du zarte Jugend, gwöhn dich von Kindheit auf $z u$ Gottesfurcht und Tugend, folg nicht dem bösen Hauf.

\author{
11. Christ meinem Herrn ich nun befehl \\ die ganze Schul zusamm \\ und all darin mit Leib und Seel, \\ blüht, wachst in Gottes Nam. \\ $O$ allerliebste Kinder, \\ nehmt eure Zeit in Acht, \\ Gott macht eur Arbeit linder. \\ Hiermit zu Guter Nacht.
}

My dearest colleagues all,

Be true to your God,

He will certainly reward you

One day with many blessings.

And, oh you tender youth, Accustom yourself from childhood on To virtue and fear of God, Follow not the wicked multitude.

To Christ, my Lord, I now commend The entire school together And all therein with body and soul, Blossom, grow in God's name

Oh dearest children,

Be attentive of your time, God makes your work easier. With these words, good night.

It might be noted that Schein did not limit his application of personification exclusively to the dead, for it is apparent in a number of the hymns that it is in fact the congregation that is portrayed rhetorically. Most of the texts in these compositions are penitential in character, as in nos. 228, 240, and 239 (which is in fact a Kyrie trope). Others, including nos. 226 and 227, are consolatory expressions of faith. One of the most frequently performed funerary pieces in the seventeenth century was "Nun lasst uns den Leib begraben" (no. 241), which served doubly as a means of consoling the mourners and of signalling both the removal of the body and the conclusion of the ceremony itself. The rhetoric of personifying the congregation, if different in approach to animating the dead, is as intriguing as it was effective. With these compositions, the poet/composer was able to employ the choir to personify the congregation. In this abstract way, he was able to place before the congregation an eloquent Christian model worthy of emulation. On the other hand, these compositions 
could sometimes be sung by the real congregation. The mourners in these circumstances thus personified themselves, so to speak, imbued with the spirit of an idealized congregation, collectively giving voice to personal sentiments which they in fact felt or should have felt. Needless to say, integrated with these congregational expressions of penitence and consolation was no small amount of Church doctrine; indeed, such doctrine was the very essence of these texts. Through the personification of the congregation in cantional hymns, the mourners consoled themselves from within and one another from without, reinforcing simultaneously their faith in the Church.

Compositions in dialogue constitute a second major category of funeral music in which composers employed musical-rhetorical personification. In rhetoric, dialogue has always been integral to the discussion of literary prosopopoeia. Quintilian's treatment of rhetorical dialogue is found together with the rest of his discussion of prosopopoeia, and it is considered by him to be the Greek equivalent to the Latin sermocinatio (Institutio oratoria 9. 2. 31). In his discussion of prosopopoeia, Quintilian says of dialogue that "without sacrificing credibility we may introduce conversations between ourselves and others, or of others among themselves, and put words of advice, reproach, complaint, praise or pity into the mouths of appropriate persons" (Institutio oratoria 9. 2. 30).

Quintilian's view of oratorical dialogue was readily adopted by German rhetoricians of the seventeenth century. This can be seen in the heading to Meyfart's chapter on prosopopoeia in the Teutsche Rhetorica: "What the noble prosopopoeia is. Likewise, what dialogue is to the orators" (Was die Edle Prosopopoeia sey. Item was Dialogismus bey den Redenern sey) (Meyfart 1634: 387). To Meyfart's mind, dialogue is so closely related to prosopopoeia that he makes no attempt whatsoever in this chapter to discuss it independently, apparently understanding dialogue merely to be a compound application of prosopopoeia. Dialogue (ars colloquendi) was used throughout the Baroque as a didactic device which conveniently allowed the writer to present lucidly both sides of any argument. The study of the Colloquia (1518) of Erasmus and the Paedologia (1518) of Petrus Moseallanus continued throughout Protestant Germany in the seventeenth century, and the Progymnasmata latinitatis sive dialogi (1588-94) by Jacobus Pontanus were still in use in Germany well into the eighteenth century, as were the classical dialogues of Cicero and Terence (Barner 1970: 290). The relevance of rhetorical dialogue to German education was still acknowledged in mid-eighteenth-century rhetoric manuals such as Carl Gotthelf Müller's Die Weisheit des Redners (Jena 1748) (Stötzer 1962: 224-25).

Dialogue and music had already enjoyed a long association prior to the seven- 
teenth century. As early as the tenth and eleventh centuries, dialogue had been used in the composition of sacred tropes. The effectiveness of the musical dialogue, as well as the number of possibilities for employing it, increased substantially during the sixteenth century, owing in part to the development of the polychoral style first heard in Venice and Florence. The dialogue received renewed impetus in the early years of the Baroque with the development of the monodic and concertato styles. Musical dialogue is defined by Michael Praetorius in the Syntagma musicum III in 1619 as "a conversation, as when one answers the question put by another, or similarly when one alternates with another in chorus" (Praetorius 1619: 3:16) ${ }^{7}$ The term is still current in the first third of the eighteenth century, as seen in Johann Gottfried Walther's Musikalisches Lexikon in 1732:

Dialogue . . . is a composition of at least two voices, or as many instruments, which are heard alternately and, when they come together at the end, make a trio with the basso continuo. There are also compositions for 2,3 and 4 choirs, which alternate conversationally. (Walther 1732: 204)

Most of the early influence on the Baroque development of the dialogue in Germany was exerted directly and indirectly by Italy. In addition to the music of Gabrieli and his school, an early seventeenth-century influence was Lodovico Viadana's widely disseminated Cento concerti ecclesiastici of $1602 .^{9}$ Musical dialogue was quickly accepted by German composers of the late

. ein Gespräch / als wenn einer dem andern vff beschehene Frage antwortet / vnd eins vmbs ander gleich per Choros vmbgewechselt wird." (Translation in KirwanMott 1981: 1:323.)

8 "Dialogo ... ist eine Composition wenigstens von zwo Stimmen, oder so viel Instrumenten, so wechsels-weise sich hören lassen, und wenn sie am Ende zusammen kommen, mit dem $G$. B. ein Trio machen; es giebt aber auch Compositiones auf 2. 3. und 4 Chöre, so Gesprächs-weise Alterniren."

Book I of Viadana's Cento concerti ecclesiastici was published by Nikolaus Stein in Frankfurt-am-Main as early as 1609 . The complete edition was later published by Stein (Frankfurt, 1620). The concertato style of Viadana was also quickly taken up by composers in Germany, first by Gregor Aichinger in his Cantiones ecclesiasticae trium et quatuor vocum . . . cum Basso Generali et Continuo in usum Organistarum (Dillingen, 1607) and by Adam Gumpeltzhaimer in Book II of his Sacri concentus (Augsburg, 1614). See Redlich 1968: 536-37, 544-49. For a more comprehensive discussion of the sacred music dialogue in seventeenth-century Germany, see Hudemann 1941, Noack 1954, Nutter and Whenham 1980, and Kirwan-Mott 1981: 1:323-46. 
sixteenth century for musical and textual reasons. Musically, it was well suited to the tastes of the Baroque German audience, and sectional form and elements of contrast inherent in madrigal and motet composition (which naturally lent themselves to setting textual dialogues) would have appealed to German composers. Textually, the dialogue, when employed in a sacred context, as was often the case, was an extremely effective dialectical method of presenting Church dogma and underscoring doctrinal points.

There are two principal types of dialogue found in seventeenth-century funeral music: one is strictly textual, as in the case of the cantionale, the other both textual and musical. Compositions of the first type are strophic works for chorus in which two or more persons, invariably including the deceased, are textually personified. A typical example of this kind of choral dialogue is a work by Severus Gastorius (1646-82) of Jena written for the funeral in 1679 of a certain Herr Wilken von Berglasen (Gastorius 1679). We know for certain that the work was written as a dialogue between the mother and her dead son not on the basis of internal musical evidence but because verses 1, 3, 5, 7 and 8 are labelled "Mutter" and each of the rejoining verses, 2, 4 and 6, bears the heading "Sohn." The music, printed in score format, is written in a simple, four-part (SATB) homophonic style with basso continuo and is used unchanged for each of the eight verses. The text, on the other hand, is illustrative of the approach to the majority of funerary dialogues of the Lutheran Church in which the deceased and the mourners are represented. At the beginning of the composition, the grieving mother laments the loss of her son. Through the text ascribed to the personified son, the mother is consoled with assurances that his death was God's will and that his soul was in heaven. Unable as a Christian to refute theological or doctrinal arguments of this type, the personified mother of the dialogue accordingly abandons her sorrow and accepts consolation in the knowledge that her son has achieved salvation and eternal life. In the performance of this work at the funeral, the real mourners would be expected to identify themselves with the personified mother of the dialogue and would find themselves similarly comforted by the deceased's arguments.

Composers were able to punctuate the greater distinction between personified characters of funerary dialogues by employing either real or implied polychoral effects. Although the individual persons depicted in the music were still represented chorally, the application of opposing bodies of sound was a more effective means of suggesting multiple characters than was the single chorus in cantional-like works. As an example of this type of composition, one can cite "Ach Gott wie ist mein Hertz betrübt" composed in 1656 by the Eisenach cantor Theodor Schuchardt (1601-77) for the funeral of Johann Heinrich Weisse, who died in infancy at just twenty-two weeks of age (Schuchardt 
1656). In this work for two four-voice choirs, the chorus primus identified as the "Quereus" represents the father, and the chorus secundus called the "Respondens" personifies the infant son. Schuchardt appropriately assigns the text of the father to the first choir comprised of lower voices (ATTB), and the text of the responding son is given to a choir of higher voices (SSAB). Throughout this work, the two choirs perform in alternation. The bereft "father" laments his loss, while the "son" comforts his father with Church doctrine and furthermore chastises him for vainly placing value on worldly things. Following the sixth verse is an additional musical section labelled "Conclusio," which is derived musically from the material of the chorus secundus. In the Conclusio the two choirs alternate at much shorter intervals, with the cadence of each textual and musical clause of the chorus secundus being quietly echoed by the chorus primus. We can see, at this point, the father gradually moving towards rhetorical assent with the son; instead of textually and musically contesting his personified son, the father begins to echo his words and music. Assent is ultimately achieved in this work as the personified father and son are united textually ("wenn wir zusamen kommen") and musically when, for the first time in the composition, the two choirs join forces coinciding with a meaningful move from duple to a joyous triple metre (see Example 1).

In 1651 Simon Brancovius, cantor in Ranis, composed a polychoral composition for nine voices and basso continuo on the death of Frau Agna Elisabeth von Breitenbauch (Brancovius 1651). The composer points out on the title page of the work that the music was conceived "for two choirs, as though the Most Noble deeply distressed Herr von Breitenbauch in the first choir [ATB], in the second [SSATB] however the Most Noble Frau von Breitenbauch, upon parting, as it were, thus spoke." ${ }^{10}$ Appropriate to a realistic if abstract musical depiction of the widowed husband and the deceased wife, the two choirs emphasize, respectively, the lower and higher voice types.

Brancovius did compose a soprano part for the chorus primus and comments on it at the beginning of the part book as follows:

The first choir, when it alternates with the second choir, always proceeds without the Discant. At the end, however, the following Discant is added to it, and not without special Effect; for such a Discant can also represent, as it

10 “... uff zwey Chor / als wenn im ersten Chor der Hoch Adel. hochbetrübte Herr von Breitenbauch / Im andern aber die H. Adl. Fraw von Breitenbauch zum Abschiede gleichsam also redeten ...." 


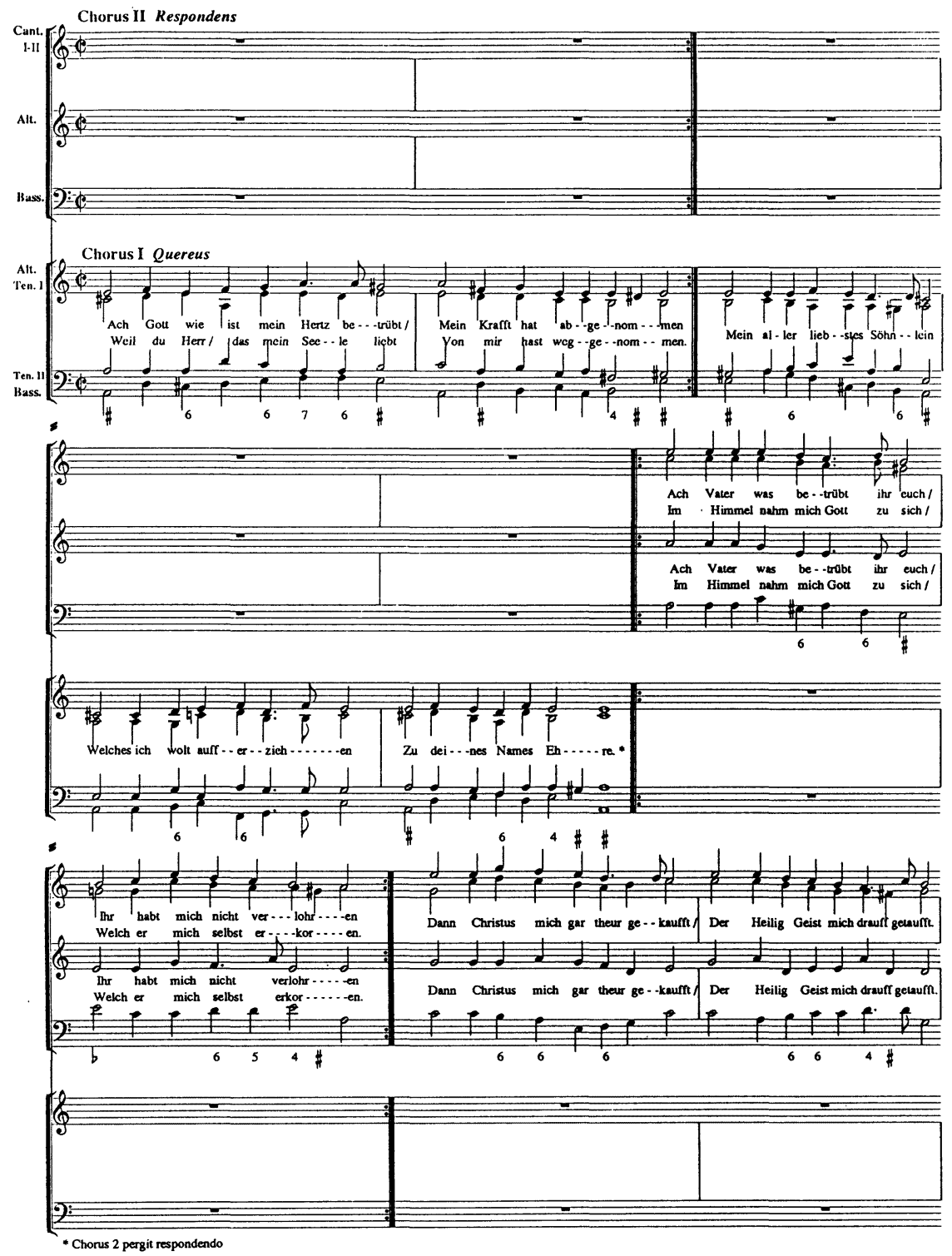

Example 1: T. Schuchardt, "Ach Gott wie ist mein Hertz betrübt". 


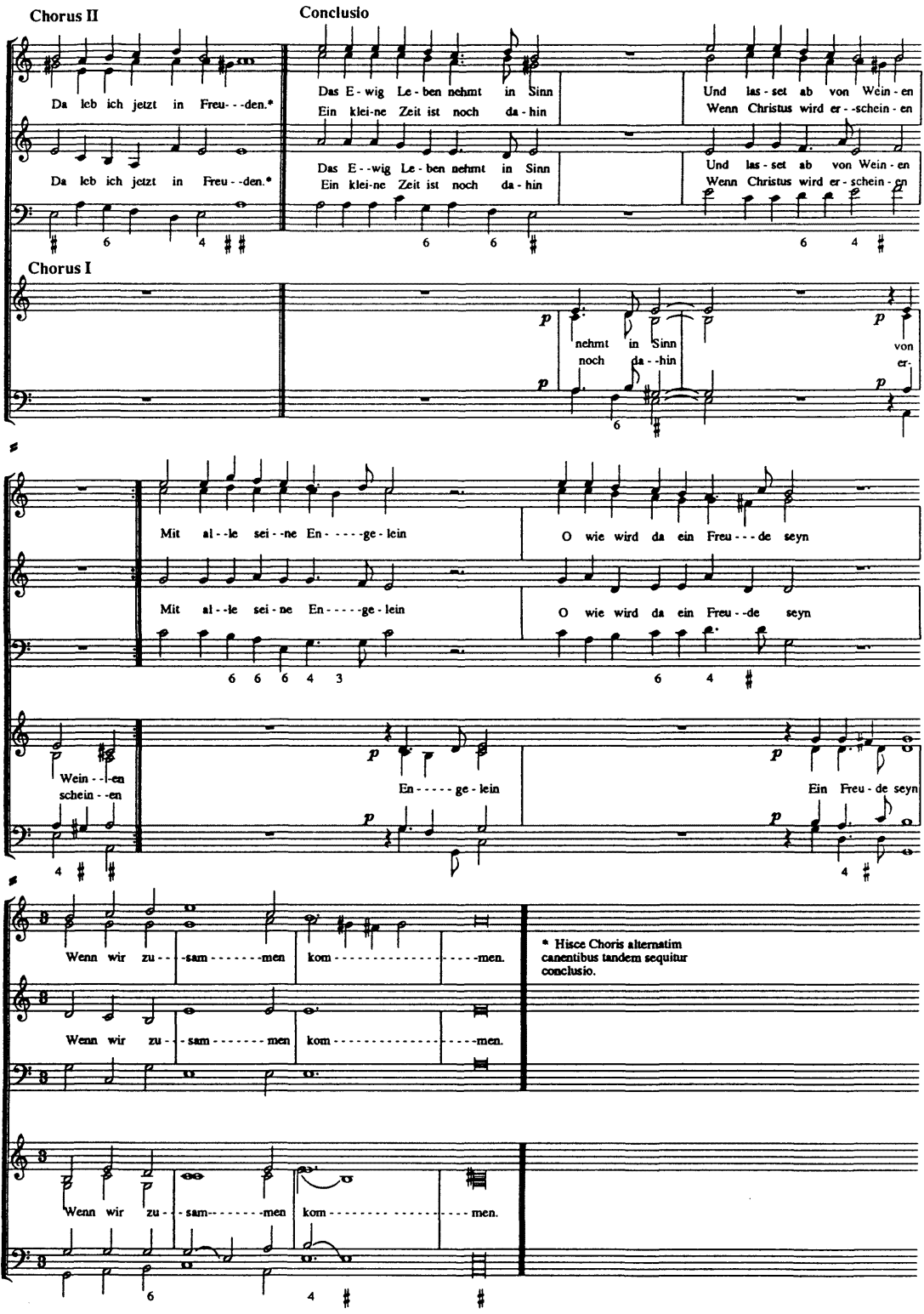


were, in addition to the Most Noble Lord of Breitenbauch, other attending Most Noble mourners . ... ${ }^{11}$

The composer goes on to say that, in order to help the sopranos of the chorus primus stave off boredom because of the prolonged silence, he included the full text of the work for them that they might at least follow along. As each of the personifying choirs enters, the text bears such headings as "The Most Noble Lord of Breitenbauch speaks here," 12 which is followed by "The Most Noble, now blessedly disembodied Lady of Breitenbauch thus responds, so to speak, to her ... distressed widower in the following way." ${ }^{13}$ In the second entrance of the chorus secundus, the personified woman "renounces this transitory world," 14 and concludes with a "Valediction to the gathering of Most Noble Friends." 15 The work concludes with the two choirs collectively addressing a petition to God.

Kaspar Förkelrath, organist at St Marien in Flensburg, set music to an allegorical dialogue in a work composed in 1671 for the funeral of Sibylla Ursula, Duchess of Brunswick, Lüneburg, etc. (Förkelrath 1672). The dialogue takes place between Jesus, "The Victorious Soul" (Die siegende Seele) - i.e., the late Duchess - and a third group identified as "The Choir of Angels" (Der Engel Chor). More so than in the previous compositions, the application of prosopopoeia in Förkelrath's composition represents as closely as possible the actual voice-types of all the characters being personified. The part of Jesus is sung by a solo bass, the voice of the woman's soul is assigned to a soprano, and the angelic choir is given to a four-part chorus (SATB). In the course of the composition, Jesus offers entry into the kingdom of heaven to the deceased woman. Upon her acceptance of the offer, the metre of the music changes from duple to triple as the seraphic choir enters to welcome the victorious spirit into heaven.

11 "Der erste Chor / wenn er mit den andern Chor abwechselt / gehet immer ohne Discant, zum Beschluss aber kömmet nachfolgender Discant dazu / und nicht ohne sondern Effect, den solcher Discant neben dem HochAdel. Herrn von Breitenbauch auch andere HochAdel. angehörige Betrübte gleichsamb repraesentiren kan . . .."

12 "Der Hoch Adel. Herr von Breütenbauch redet hier . . . ."

13 "Die Hoch adeliche numehr seel. abgeleibte Fr. von Breuttenbauchin / respondiret gleichsamb Ihrem . . . betrübten Herren Witber / nachfolgender massen also . . .."

14 “. . vernichtet diese vergängliche Welt, . . "

15 “... Valediction an die sämbtliche Hoch Adel. Freundschafft." 
The overall design of this funeral composition by Förkelrath differs considerably from that of the other dialogues mentioned thus far. First, a greater degree of realism is achieved through the portrayal of Christ and the deceased by appropriately matched solo singers and of the angelic choir by the four-part choir. Second, the characters represented in the music are, in a sense, wholly allegorical - that is, a personification of the mourners is noticeably absent. Third, as a consequence to this, the tenor of the text had necessarily to assume a literary approach other than the usual one of consolation and admonition. ${ }^{16}$ What the congregation heard was a most persuasive, semi-dramatic realization of a narrative biblical text - a striking case of a composer's exploiting the Augenkultur of his time.

The texts of the dialogues are clearly didactic in nature, comparable in their intent to most of the tenets voiced in Baroque funeral sermons. Christoph Weissenborn states near the beginning of his Politischer Leich-Redner of 1707 that the purpose of the Abdankung, a type of funerary oratory, was to praise the deceased ( $L o b$, laudatio), to lament the passing of the deceased (Klage, lamentatio), to console the mourners (Trost, consolatio), and to thank the congregation for attending the service (Danksagung, gratiarum actio) (Weissenborn 1707: 6). Honouring the deceased and lamenting his or her death are in effect the same act, and thanking the congregation for their attendance is a matter more of formality than of necessity. Thus, we are able to see that the two basic elements of funerary dialogues and sermonic oratory are essentially the same: lamentation and consolation. Through prosopopoeial dialogues the mourners, in one sense, are given a direct line of communication with the hereafter in that they, the living, are personally addressed by the dead. At the beginning of the dialogue, the personified mourners give voice in music to sentiments which would reflect the emotional state of the real mourners. In the course of the composition, like a funeral sermon reduced to its essence, the soul persuades the survivors to abandon their sorrow and to replace it with joy in the knowledge that the deceased, according to his or her personal testimony, was safely and happily in heaven. It was the intention of the composers of the text and music that the individual and collective mourn-

16 In the description of the funeral ceremony at the beginning of the published Leichenpredigt of 1672, the unidentified author writes that the performance of Förkelrath's music was followed by the singing of the duchess's beloved "Herr Jesu Christ wahr Mensch und Gott" and the reading of the sermon based on Revelations 3:5. This ordering is somewhat unusual for the time in that the commissioned music was most often after the sermon had been read. Because Förkelrath's dialogue and the sermon are both based on the same scripture, the sermon in effect becomes a literary exegesis of the music. 
ers would in this way - and a more persuasive method can scarcely be imagined - feel vicariously consoled.

A third type of funeral music in which prosopopoeia was employed is the solo aria. Compositions of this type were most frequently written as continuo arias, less often as consort arias for solo voice and accompanying instrumental ensemble. Although the representation of a mourner in the solo aria was a persuasive application of musical-rhetorical personification, the animation of the deceased was used more frequently. There are two possible means of personifying the deceased. The first is characterized by compositions in which the deceased is personified textually by a solo singer but where the quality of voice does not correspond to that of the deceased - for example, a soprano or alto voice designated to personify an adult male. One example of this kind of prosopopoeia is found in the single extant work by Gottfried Ernst Brechthold, the school rector in Neustadt (Brechthold 1668). The aria was written for the funeral of Brechthold's father in 1668, and we know from the title of the work that it was in fact written as a personification of Brechthold's father as he "takes his leave of this world, from his remaining wife and children, and thus addresses them from the grave." 17 Appended to the end of the nine verses of text is a short note in which the composer reveals that he portrayed his father in this work as a way of offering consolation both to himself and to the bereft family. Although this composition for solo voice and (unfigured) basso continuo is a clear instance of musical-rhetorical prosopopoeia, the composer, for some reason, elected to assign the vocal part to a soprano voice. This raises the question of why Brechthold would deliberately portray his father with a soprano voice. Perhaps there was no suitable adult male available at the time to sing the aria, or perhaps finding a voice to correspond to that of the deceased was not an important consideration for the composer. It is possible, too, that Brechthold sought to evoke a more ethereal or transcendent image of his father's spirit by employing a soprano. (Boy sopranos were traditionally used to portray angels in Baroque music.) A fourth and plausible performance alternative is that the vocal line, though written for soprano voice, could have been sung comfortably an octave lower by a tenor voice, as was occasionally practised in the Baroque.

German composers of funeral music as a rule appeared to be mindful of the sex of the deceased when setting solo melodies to prosopopoeial texts. $\mathrm{Nu}$ merous instances of solo arias in which the voice of the deceased is accurately depicted occur in the Siebender Theil der Arien (Königsberg 1648), an anthology of occasional music by Heinrich Albert (1604-51). One of the arias in

17 “... von seinem hinter-lassenen Eheweib und Kindern den Abschied aus dieser Welt nimmet / und sie gleichsam aus dem Grabe also anredet." Ibid. 
this collection, "Gedenkt wie mich der Tod" (no. 81), written for soprano and basso continuo, is identified by Albert as the "Last Address of a Once Proud and Now Dead Maiden" (Letzer rede Einer vormals stoltzen und gleich jetzt sterbenden Jungfrawen). Characteristic of Albert in many of these compositions, the aria is written more in a spirit of admonition than of consolation, as can be seen in the opening verse:

Gedenkt wie mich der Tod

So scheusslich hat gemacht

Ich tanze nur vor an

ihr werdet folgen müssen.
Consider how hideous

death has made me

I only lead off the dance

you shall have to follow.

Interestingly in the score, on the word "tanze," there is a shift from duple to triple metre in a rare musical reference in Baroque funeral music to the Totentanz.

H. J. Moser, in his biography of Heinrich Schütz, writes that Albert's prosopopoeial compositions of the more graphic type "were often in rather bad taste" (Moser 1959: 487) - possibly in reference to such arias as Albert's setting of Robert Roberthin's "Wie lieg ich hie!," no. 32 in the Siebender Theil der Arien. This composition, presumably of funerary origin, is described as the "Address of a Dead Maiden from the Grave" (Rede einer verstorbenen Jungfrau auss dem Grabe) in which the personified corpse becomes a decaying but animate haven for worms. In these instances at least, van Ingen demonstrates greater sympathy than does Moser for the world view of Protestant Germans in the seventeenth century, realizing that, for the Baroque poet, the theological ends - in this case effective admonition - justified the poetic means:

But that is exactly what the poets wanted to achieve! In order to work at any cost, no method was too crass, no place too vile. The Baroque helped itself to all things, animate as well as inanimate, to explain them emblematically. Therefore, man must suffer at every stage of his life. For the memento mori, he becomes all the more useful as a dying or dead man: his final hours, his final resting place and his decaying, putrefied body provide this genre with the most effective means of intensification.... He paid no attention to taboos; indeed, he was probably unaware of any. (van Ingen 1966: 299) $)^{18}$

18 “Aber das wollten die Dichter gerade erreichen! Um zu wirken um jeden Preis, war kein Mittel zu krass, kein Ort zu garstig. Das Barocke bediente sich aller Dinge, lebendiger wie lebloser, sie sinnbildlich auszudeuten. Dazu muss auch der Mensch, auf allen Stufen seines Lebens, herhalten. Für das Memento mori wird er erst recht als Sterbender oder als Toter brauchbar: Seine letzten Stunden, seine letzte Ruhestätte und sein zerfallener, verfaulter Körper führen dieser Gattung die effektreichsten Steigerungsmittel zu ... . Um Tabus kümmerte er sich nicht; er kannte sie wohl auch nicht." 
In the same way that graphic extremes pervaded much of the prosopopoeial funerary literature in the seventeenth century, composers, too, used every artistic means at their disposal to portray as vividly as possible the animate presence of the deceased, as we shall now see. The last type of musicalrhetorical prosopopoeia to be considered here is characterized by textual personification of the deceased, by representation of the deceased by a solo voice, and by an added physical dimension through the spatial displacement of the personifying voices. ${ }^{19}$

Heinrich Schütz's Musikalische Exequien (SWV 279-81), composed for the funeral of Prince Heinrich Posthumus von Reuss (1572-1635), presents one of the most striking instances of this particular type of musical-rhetorical prosopopoeia. Prince Heinrich was an educated and able ruler, well travelled, diplomatically skilled, and socially adroit (Jung 1962: 19). A generous patron of the Church, education and the arts, he was himself a proficient instrumentalist and a vocalist capable of singing "the bass in many fine motets and anthems..." (Graulich 1973: xxv). Heinrich Posthumus's love of music was such that even his servants were hired primarily for their musical qualities and only secondarily for their domestic skills (Graulich 1973: viii, xxv [trans.]). Though an aristocrat, he did not hesitate to cross class barriers to partake in musicmaking with lowly Musikanten ${ }^{20}$ and at times acted as Capellmeister, to use his own term, during church services at the court chapel. ${ }^{21}$

Upon his death on 3 December 1635, Heinrich Posthumus's body was embalmed, a practice common among those born into the aristocracy, and laid in state in the chapel of Schloss Osterstein, remaining there until February 1636. The final burial ceremony was performed at the St Johannis Church on 4 February, meaningfully and no doubt intentionally the burial day of the bibli-

19 The application of this kind of prosopopoeia is the focus of an independent and more detailed study. See G. S. Johnston, "Rhetorical Personification of the Dead in Seventeenth-Century German Funeral Music: Heinrich Schütz's Musikalische Exequien (1636) and Three Works by Michael Wiedemann (1693)," The Journal of Musicology, in press.

20 Schütz praises this aspect of Heinrich Posthumus's character in the elegy which prefaces the published version of the Musikalische Exequien of 1636. See Dieter Krickeberg, Das protestantische Kantorat im 17. Jahrhundert: Studien zum Amt des deutschen Kantors, Berliner Studien zur Musikwissenschaft, ed. by Adam Adrio, vol. 6 (Berlin: Verlag Merseburger, 1965), pp. 79-80.

Quoted in Graulich (1973): xxv. 
cal Simeon (Luke 2:25-35). Throughout this final ceremony, the body of Heinrich Posthumus presumably lay beneath the pulpit. Whether or not the coffin was open during the ceremony is unknown, though many published seventeenth-century Leichenpredigten include illustrations of open as well as closed coffins, and sermons also make occasional reference to the body, suggesting an open coffin. Naturally an open-casket funeral would prove to be emotionally more affecting owing to the added visual impact.

It was in the course of this closing ceremony that Schütz personally directed the performance of the Musikalische Exequien. The ceremony began with the quasi-missa brevis of Schütz's Musikalische Exequien. Following the sermon based on Psalm 73:25 (HErr/wenn ich nur dich habe), the choir performed the second section of Schütz's work, a motet setting of the same text for two four-voice choirs. Rather than drawing the ceremony to a close with a Collect and Benediction after the performance of the motet, which would have been the customary procedure, the choir immediately started in on the third portion of the work. Introduced by the tenor's intoning of the Canticum Simeonis (Luke 2:29-32), "Herr nun lässest du deinen Diener," the five-voice chorus primus (SATTB) continues fortiter with a homophonic statement of "in Friede fahren." This choir, according to Schütz's directives, was to be stationed close to the organ, an arrangement which in itself was not at all unusual. After the first four breves and a drop in the dynamic level from fortiter to submisse, the voices of the chorus secundus (SSBar.) enter in imitative succession, from highest to lowest voice, with a completely different text taken from Revelations 14:13, "Selig sind die Toten, die in dem Herren sterben," later incorporating additional text from the apocryphal Wisdom of Solomon (3:1) (see Example 2).

The setting of the movement and Schütz's directions for its performance are described in some detail in the prefacing "Special Index of the Musical Items contained in this slight work together with the Ordinances for the gracious reader" (Graulich 1973: xxxix). ${ }^{22}$ The relevant ordinance is the third and bears the heading "III. Ordinantz des Gesanges Simeonis: HErr nun lässestu deinen Diener in Friede fahren." One sees in the ordinance that Schütz composed this work with conscious consideration of its rhetoric in general and of the personification of the dead in particular. Beginning with the invention, Schütz set out to represent in music the joy of the disembodied spirit in the company of angels. First of all, the textual differences contribute to the perception of disembodiment. The text for the chorus primus from the Can-

22 Facsimile reprint in Graulich 1973: xlii. 


\section{III}

Canticum B. Simeonis: „Herr nun lässest du deinen Diener“

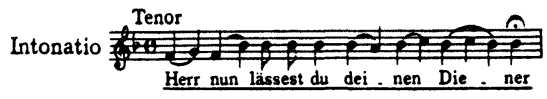

Sehr langsame Viertel

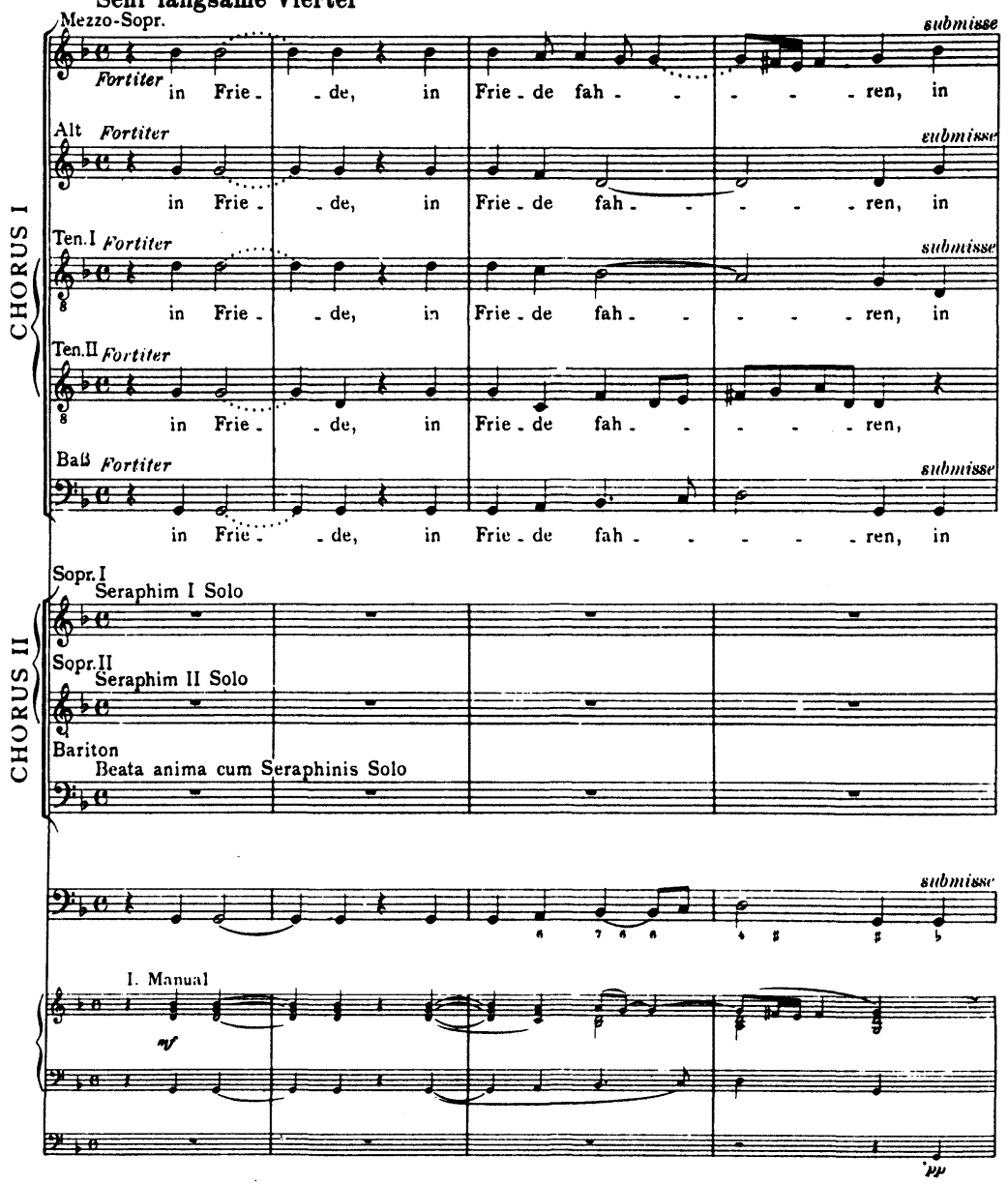

Example 2: H. Schütz, Musikalische Exequien, Canticum B. Simeonis: "Herr nun lässest du deinen Diener" (SWV 281), bars 1-10. Copyright 1982 by Breitkopf \& Härtel Musikverlag, Leipzig. Reprinted by permission. 


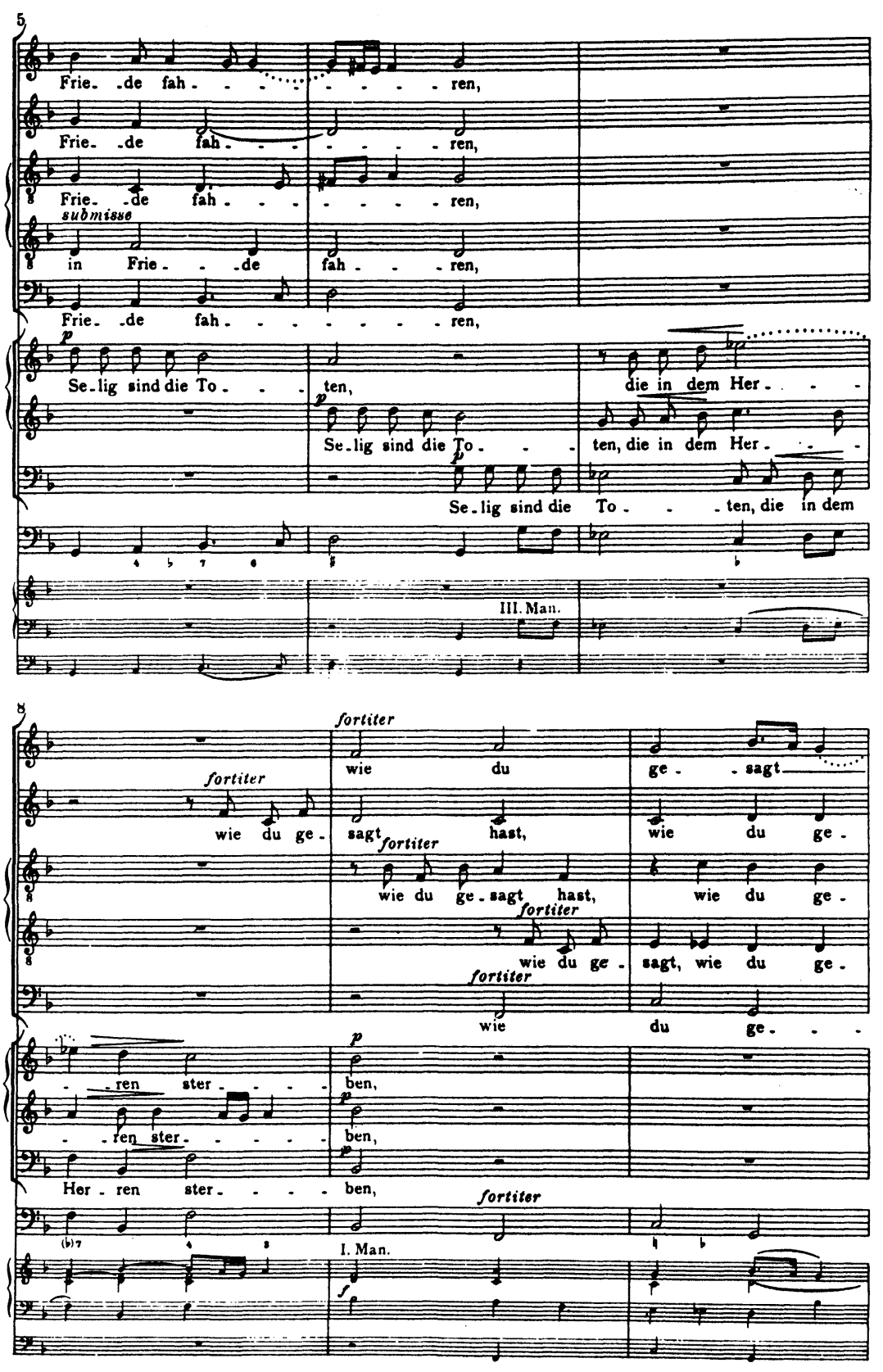


ticum Simeonis, had long been employed choraliter to accompany burials at Lutheran funerals and, in this case, is clearly a representation of the mourners. The text, petitionary in nature and remindful of promised resurrection, is addressed to God. The text of the three-voice chorus secundus, on the other hand, is a consolatory response in that it is an affirmation of a covenant of death and resurrection that exists between God and mankind. Interestingly, this latter text seems to lack the almost questioning emotional charge of the Canticum Simeonis; rather is it much more ethereal in tone: a distanced, somewhat apathetic statement of fact made in what was an extremely pathetic situation.

Second, Schütz judiciously selected the particular voices to be used in the chorus secundus. The voices of the angels, as was common at that time, ${ }^{23}$ are assigned to two sopranos labelled Seraphim I and Seraphim II. Schütz states in the ordinance that the third voice, the "Beata anima cum Seraphinis Solo," significantly, was written for "a baritone or high bass." Convenient though it was that a bass voice would provide the necessary harmonic foundation for the concertato choir, Schütz was no doubt thinking of Heinrich Posthumus's reputation as a capable musician, and specifically as a singer who could handle "the bass in many fine motets and anthems." Schütz clearly makes every effort in this work to establish that this low voice is in fact a personification of Heinrich Posthumus, and one is tempted to conclude from the evidence that the Prince himself was a baritone. ${ }^{24}$

Third, the spatial displacement of the concertato chorus secundus figures prominently in Schütz's personification of Heinrich Posthumus. Schütz had long been acquainted with the acoustic and dramatic possibilities of chori

Hans Joachim Moser writes that people travelled long distances to hear Christmas matins at the Reuss Court, and that in 1623 Heinrich Posthumus personally directed a performance for which the choir boys were dressed as angels wearing green wreaths and holding burning torches (Moser 1959: 156).

24 This suggestion may be supported by the statement in the biographical Lebenslauf of Reuss's funeral sermon where he is credited with having been able to sing the bass part in many - but not all, one should note - motets and anthems. In Baroque funerary personalia, there was a much greater, and widely acknowledged, tendency to exaggerate the deceased's qualities than to diminish them, as would otherwise be the case here. Because of the growing tendency in Leichenpredigten towards excessively hyperbolic descriptions of the attributes and achievements of the deceased, "funeral sermons" (Leichenpredigten) came increasingly to be referred to in the seventeenth century as "lying sermons" (Lügenpredigten). See Lenz 1975: 43-44. 
spezzati and uses the device to good effect in the Musikalische Exequien. In his personification of the Prince, Schütz achieves the desired effect of the disembodied soul by placing the chorus secundus off in the distance, most likely in the gallery. Since the music is written sectionally to allow for the alternating polychoral effect between the two choirs, Schütz saw additional prosopopoeial possibilities. He takes advantage of the ample pauses between entries in the chorus secundus, suggesting that the trio be duplicated or even triplicated. The additional choirs were then to be placed in remote parts of the church, again probably in the gallery. Most likely the singers representing the seraphim and Heinrich Posthumus were not visible to the congregation, an artful ploy Schütz had been aware of as early as 1623 (MacClintock 1979: 142) ${ }^{25}$ If Schütz himself elected to replicate the voices, as he prescribes in the ordinance, and to stagger the entries of the chorus secundus, the congregation would have heard not only the personified voice of Heinrich Posthumus comfortingly singing from above, but also the personifying voices, incorporeal and migrant, emanating from different but indeterminate parts of the church.

Schütz composed the last section of the Musikalische Exequien with full intentions of making a powerful emotional impact on the assembly of mourners, writing at the end of the relevant ordinance that, by personifying the Prince in this way, he hoped the "effect des Werkes" might be greatly increased. The emotional power of personification must have had a strong effect upon the congregation of mourners. During the preceding two months, the body of Heinrich Posthumus lay lifeless, first in state in the court chapel and later in the Johanniskirche. During that period the idea of death must have been pervasive in the Gera Court, manifested by the presence of Heinrich Posthumus's remains. Although there was the theological guarantee that a Christian death was always followed by resurrection and eternal life, present in the church where those beliefs were professed lay the body of Heinrich Posthumus, concrete evidence that death was the reality, resurrection a promise. Moments before the interment which ended a prolonged, stressful and exhausting emotional period, it must have come as nothing less than a shock to the unprepared and unsuspecting congregation suddenly to hear the Prince's disembodied voice singing from above in the heavenly company of angels, uttering valedictory words of assurance to his family and friends. Through prosopo-

25 Schütz concludes his preface to the Historia der Auferstehung Jesu Christi with the statement: "It should be kept in mind that this History will be performed with better grace or effect if only the Evangelist is seen, the other personages and others remaining hidden." 
poeia, Schütz offered the mourners tangible evidence of the resurrection, evidence as concrete and incontrovertible as Reuss's corpse was of death.

Although the rhetorical personification of the dead in seventeenth-century German funeral music can be appreciated as an approach to composition, its persuasive power and dramatic effect are best understood when one bears in mind the original context: the heavily shadowed interior of a church draped in black; the bereft family and friends, the clergy, the musicians and attendants likewise in black; the deceased however in white, softly illuminated by the surrounding candlelight. Musical-rhetorical prosopopoeia was indeed powerful: it could console the mourners, and could also admonish, instruct and enlighten them. It is not unreasonable to suggest that composers, having witnessed the effectiveness of prosopopoeia in funeral sermons, would have consciously availed themselves of the techniques and devices of sermonic oratory, adapting them to their own mode of expression. In so doing, composers developed a persuasive musical rhetoric, a rhetoric as effective as, and at times more effective than, its literary counterpart.

\section{REFERENCES}

\section{ALBERT, HEINRICH}

1648: Siebender Theil der Arien, etlicher theils geistlicher: sonderlich zum Trost in allerhand Creutz und Widerwertigkeit, wie auch zur Erweckung seeligen Sterbens Lust. . . Königsberg. London, British Library, G. 62. b.

BARNER, WILFRIED.

1970: Barockrhetorik: Untersuchungen zu ihren geschichtlichen Grundlagen. Tübingen: Max Niemeyer Verlag.

BRANCOVIUS, SIMON.

1651: Musicalische Christliche Einbildung eines recht beweglichen Clag- und Trost-Gesprächs Vff das früzeitige doch selige Absterben... Agnae Elisabethen von Breitenbauch ... Vnd Bey dero Adelichen LeicheProcession, so den 21. Julii Anno 1651. angestellet wurde / uff zwey Chor... Mit 9. Stimmen componiret. .. . Jena: Caspar Freyschmied. London, British Library, Hirsch III 666.

COOPER, LANE.

1960: The Rhetoric of Aristotle: An Expanded Translation with Supplementary Examples for Students of Composition and Public Speaking. Englewood Cliffs, N.J.: Prentice-Hall Inc.

CORBETT, EDWARD P. J.

1971: Classical Rhetoric for the Modern Student. 2nd edition. New York: Oxford University Press. 
DYCK, JOACHIM.

1966: Ticht-Kunst: Deutsche Barockpoetik und rhetorische Tradition. Ars Poetica: Texte und Beiträge zur Dichtungslehre und Dichtkunst, edited by August Buck, Heinrich Lausberg and Wolfram Mauser, Band 1. Bad Homburg vor der Höhe: Verlag Dr. Max Gehlen.

FÖRKELRATH, KASPAR.

1672: Christliches Sterb-Lied . . der . . Sibyllae Ursulae . . verfasset von Heningo Petersen ... und Anno 1672 den 6. Febr. gesungen und musiciret. Hamburg: Georg Rebenlein. Wolfenbüttel, Herzog-August-Bibliothek, Gn. $4^{\circ} 1592(2)$.

\section{GASTORIUS, SEVERUS.}

1679: Klag- und Trauer-Gespräch bey Leich-Begängnuss dess . . Herrn Wilken von Berglasen . . . den 18. Augusti des 1679sten Jahres . . in einer Arie gesetzet. Jena: Johann Werther. Munich, Bayerische Staatsbibliothek, Slg. Her $0238 / 5$.

GRAULICH, GÜNTER, PAUL HORN and KLAUS HOFMANN.

1973: Preface to Heinrich Schütz, Musikalische Exequien. Op. 7., Stuttgarter Schütz-Ausgabe, edited by Günter Graulich, vol. 8. Neuhausen-Stuttgart: Hänssler Verlag, 1973.

\section{HUDEMANN, HANS-OLAF.}

1941: "Die protestantische Dialogkomposition im 17. Jahrhundert." Ph.D. dissertation, Kiel University.

INGEN, FERDINAND VAN.

1966: Vanitas und Memento Mori in der deutschen Barocklyrik. Groningen: J. B. Wolters.

JOHNSTON, GREGORY S.

1987: "Protestant Funeral Music in Seventeenth-Century Germany: A Musicalrhetorical Examination of the Printed Sources." Ph.D. dissertation, University of British Columbia.

JUNG, HANS RUDOLF.

1962: "Ein unbekanntes Gutachten von Heinrich Schütz über die Neuordnung der Hof-, Schul- und Stadtmusik in Gera," Beiträge zur Musikwissenschaft 4, no. 1: 17-36.

KALDENBACH, CHRISTOPH.

1709: Compendium Rhetorices, pro Scholis in Ducatu Wirtembergico olim adornatum à Christophoro Caldenbachio. ... 2nd edition. Tübingen; first published in Tübingen, 1682.

KEMP, JOHANN.

1634: 2. Moteten, Auff den trawrigen ... Todesfall Der... Frawen ANNA 
MARIA ... Herzoginnen zu Machlenburg ... Die Erste mit 8. Die Ander mit 6. Stimmen componiret. ... Güstrow: Johann Jägern. London, British Library, K. 5. c. 28.

KIRWAN-MOTT, ANNE.

1981: The Small-Scale Sacred Concertato in the Early Seventeenth Century, 2 volumes. Studies in British Musicology, edited by Nigel Fortune. Ann Arbor: UMI Research Press.

LENZ, RUDOLF.

1975: "Gedruckte Leichenpredigten (1550-1750)," in Leichenpredigten als Quelle historischer Wissenschaften, edited by Rudolf Lenz, pp. 36-51. Cologne: Böhlau Verlag.

MEYFART, JOHANN MATTHÄUS.

1634: Teutsche Rhetorica oder Redekunst. Coburg: Friedrich Gruner. Facsimile reprint edited by Erich Trunz. Deutsche Neudrucke, series: Barock. Tübingen: Max Niemeyer Verlag, 1977.

MOSER, HANS JOACHIM.

1959: Heinrich Schütz: His Life and Work, trans. from 2nd ed. by Carl F. Pfatteicher. Saint Louis: Concordia Publishing House. [1936]

NOACK, ELISABETH.

1954: "Dialog," Die Musik in Geschichte und Gegenwart, edited by Friedrich Blume, 3: cols. 393-99. Cassel: Bärenreiter-Verlag.

NUTTER, DAVID ALAN, and JOHN WHENHAM.

1980: "Dialogue," The New Grove Dictionary of Music and Musicians, edited by Stanley Sadie, 5: 415-21. London: Macmillan.

PRAETORIUS, MICHAEL.

1614/15-19: Syntagma musicum. Wolfenbüttel. 3 vols. Documenta Musicologica, Series 1: Druckschriften-Faksimiles, no. 15, edited by Wilibald Gurlitt. Cassel: Bärenreiter-Verlag, 1958.

QUINTILIANUS, MARCUS FABIUS.

1969: The Institutio Oratoria of Quintilian. Translated by H. E. Butler. 4 vols. London: William Heinemann; and Cambridge, Mass.: Harvard University Press.

REDLICH, HANS FERDINAND.

1968: "Early Baroque Church Music," in The Age of Humanism 1540-1630, The New Oxford History of Music, vol. 4, edited by Gerald Abraham, pp. 520-49. London: Oxford University Press. 
SCHEIN, JOHANN HERMANN.

1967: Cantional oder Gesangbuch Augsburgischer Konfession 1627/45, 2 vols., Johann Hermann Schein: Neue Ausgabe sämtlicher Werke, edited by Adam Adrio, Band 2. Cassel: Bärenreiter Verlag.

SCHUCHARDT, THEODOR.

1656: Christliches Gespräch eines betrübten Vaters mit seinem abgeleibten Söhnlein. Auff den . . . Hintritt . . Johann-Henrici, des ... Herrn M. Johannis Weissen . . . Söhnleins Welches . . anno 1656 . . . entschlaffen. Mit. 8. Stimmen zu 2 unterschiedenen Choren gesetz. Gotha: Johann Michael Schall. Berlin, Deutsche Staatsbibliothek, 2 in Ee 700-3882.

\section{SILANÔ-SILESIUS.}

1693: I. N. I.! Dass das Liebreiche Andencken GOttes / der . . lezte Wuntsch eines Rechtgläubigen Christen sei; wolte Bei Beerdigung des... Herren Sigissmund-Heinrichs ... durch eine eiligst-abgefassete . . TRAUERREDE / auf gnädigst-ertheilten . . Befehl . . in einem kurtzen Entwurff zeigen.... Lauban: Johann Gottfried Dehne. Berlin, Berliner Stadtbibliothek, VII of the Grauenklostersammlung.

STÖTZER, URSULA.

1962: Deutsche Redekunst im 17. und 18. Jahrhundert. Halle (Salle): Max Niemeyer Verlag.

WALTHER, JOHANN GOTTFRIED.

1732: Musikalisches Lexikon oder Musikalische Bibliothek. Lepizig: Wolffgang Deer. Facsimile reprint edited by Richard Schaal. Cassel: Bärenreiter Verlag, 1953.

WEINHOLD, LIESBETH.

1972: "Die Gelegenheitskomposition des 17. Jahrhunderts in Deutschland," in Quellen zur Musik: Wolfgang Schmieder zum 70. Geburtstag, edited by Karl Dorfmüller, pp. 171-90. Frankfurt: C. F. Peters.

\section{WEISSENBORN, CHRISTOPH.}

1707: Politischer Leich-Redner welcher die practicabelsten Kunst-Reguln von der Invention, Disposition und Elocution derer nach der heutigen Mode eingerichteten Abdanckungen bey öffentlichen Trauer-Solennien zur Beförderung feiner Oratorischen Collegiorum durch deutliche Exempel erleutert. Jena: Heinrich Christoph Cröker.

ZELLER, WINFRIED.

1975: "Leichenpredigt und Erbauungsliteratur," in Leichenpredigten als Quelle historischer Wissenschaften, edited by Rudolf Lenz, pp. 66-81. Cologne: Böhlau Verlag. 